Environment, Biodiversity \& Soil Security
(EBSS)
http://jenvbs.journals.ekb.eg//

\title{
Effect of Biochar, Vermicompost and Polymer on Wheat and Maize Productivity in Sandy Soils under Drought Stress
}

Hesham M. Aboelsoud ${ }^{1 *}$ and Ahmed A. Ahmed ${ }^{2}$

${ }^{1}$ Improvement and Conservation Res. Dept., Soils, Water \& Environment Res. Institute (SWERI), Agric. Res. Centre (ARC), Giza, Egypt

${ }^{2}$ Central Laboratory for Agricultural Climate (CLAC) Agric. Res. Center (ARC), Egypt

$\mathbf{T}$

HE DROUGHT is one of the most important abiotic stresses limiting the crop productivity especially in sandy soils in arid and semi-arid areas. So, using soil amendments such as vermicompost (VC), biochar (BC), and polymer (PL) are more important in these areas. Lysimeter experiments with sandy soil were carried out at Sakha Agric. Res. Station, Kafr El-Sheikh, Egypt to study the effect of $0.4 \% \mathrm{PL}, 4.0 \% \mathrm{VC}$ and $1.0 \% \mathrm{BC}$ (W:W soil) on productivity of wheat (2018/019) and maize (2019) under two irrigation levels (irrigation after depletion of $50 \%$ and $75 \%$ from soil moisture. The obtained results indicated that irrigation at $75 \%$ moisture depletion (irrigation deficit) decreased plant height, 100-grain weight, grain and straw yields, water applied to wheat $(-16.8 \%)$ and maize $(-20 \%)$ compared to that with higher irrigation level (50\% depletion). Also, water productivity was slightly decreased for wheat, but it slightly increased for maize and ECe values were slightly increased due to irrigation deficit. Also, applications of soil amendments and their combinations significantly increased plant height, 100-grain weight, yield and water productivity of both crops and improved soil porosity and field capacity. The $\mathrm{VC}$ was more effective treatment followed by $\mathrm{BC}$ and $\mathrm{PL}$ treatments, while their interactions were the most effective on these parameters. Moreover, soil amendments alleviated the deleterious effects of irrigation deficit on plant growth and salt accumulation. Finally, applying BC combined with VC and PL could be recommended as a good approach to maintain long-term productivity of sandy soils and mitigate the hazardous effects of drought stresses.

Keywords: Wheat, Maize, Polymer, Vermicompost, Biochar, Drought stress.

\section{Introduction}

Drought and salinity are the major abiotic stresses that affect crop production especially in sandy soils. Drought is a major constraint to agricultural production which clearly decreases with increasing soil moisture stress (Samson et al. 2002; Saad and Abo-Koura (2018) and ElKallawy and Hefeina, 2019). Deficit irrigation greatly reduced 1000-grain weight (Emam et al. 2007), growth and grain yield of wheat (Moghaddam et al. 2012), plant height and grain yield of wheat (Akbar et al. 2010 and Aiad, 2019), while the maximum wheat yield was achieved by $84 \%$ of full evapotranspiration (Zhang et al.
2008). Also, fully irrigation greatly increased wheat grain yield (Ibrahim et al., 2005) due to a decrease in intercepted light which ultimately reduced its efficiency into economic part (Wajid et al. 2007). The grain yield and water use efficiency were affected by water stress (Ghodsi et al., 2008) whereas; wheat yield was reduced by $6 \%$ under deducing $30 \%$ of full irrigation (Wang et al., 2008). However, the soil amendments reduce the stresses of water deficiency (Ahmad et al., 2013), through improving soil chemical, physical and biological properties (Hueso-González et al., 2014 and Mann, 2011).

"Corresponding author : hm_aboelsoud@yahoo.com

Received: 06 / 05 / 2020 ; Accepted 04 / 06 / 2020

DOI: $10.21608 /$ jenvbs.2020.29442.1095

(C2020 National Information and Documentation Center (NIDOC) 
The biochar (BC), vermicompost (VC), and polymer (PL) are being used as soil amendments. BC is a solid carbon-rich organic material generated by heating biomass at 300 $600{ }^{\circ} \mathrm{C}$ under condition of limited or no oxygen (Lehmann and Joseph, 2009; Mosa et al., 2017 and Amer and El-Emary, 2018) and can be used as a soil amendment for improving soil quality and productivity (Hossain et al., 2010 and Zheng et al., 2010) because it has high porosity and large specific surface area (Obia et al., 2016). Organic amendments have to be applied every year because of its rapid decomposition (Gupta and Monika, 2016), so, more stable compounds such as BC could be alternatively used (Glaser et al., 2002). BC at 2\% improved wheat growth and increased its height by $11 \%$ (Kanwal et al., 2018), while $5 \%$ BC under salinity improved soil fertility and increased sorghum biomass yield by $25 \%$ (Edmunds, 2012). In addition, 1.5, 3.0 and $4.5 \% \mathrm{BC}$ in saline-sodic paddy soil reduced stress and promoted rice yield (Jin et al., 2018), while BC improved the legume yield in the calcareous soil in arid area (Azeem et al., 2016). Diatta (2016) reported that 20 tons $\mathrm{BC} /$ ha could improve soil fertility and crop productivity in temperate soils but had limited effects on sandy, salt-stressed soils may be due to differences in soil properties.Bayoumy et al. (2019) reported that $\mathrm{BC}$ with compost tea and gypsum improved plant height, 1000-grain weight, straw yield and grain yield of wheat in salt-affected soils.

The interests are shifted towards the organic amendments like VC, which produced from compost through the earth worms and contains essential nutrients and plant growth regulating hormones (Allardice, 2015) and it improves soil quality (Kheir et al., 2017 and Mahmud et al., 2018). Joshi et al. (2014) suggested 20 tons VC/ha as an ideal for better growth, higher plant height and total yield of wheat. Chemical fertilizers with $\mathrm{VC}$ would help to maintain the long-term soil productivity, whereas 10 -ton $\mathrm{VC} /$ ha with $50 \%$ chemical fertilizers (Muktaet al., 2015) or 15-ton $\mathrm{VC} / \mathrm{ha}+50 \%$ NPK (Suthar, 2009) was the best performance for the height and yield of plant due to presence of plant nutrients and some essential growth-promoting substances in VC. Also, VC promotes growth and productivity of wheat (Suthar, 2006 and Ibrahim et al., 2015), while VC with BC provides pathogen suppression to plants and increase crop productivity (Shoaf, 2014). Moreover, 5 tons BC with 20 tons FYM/ha (Gautam et al., 2017) or 2.5-5.0\% BC+ compost with or without the mineral fertilizer (Schulzand Glaser (2012) provide beneficial effects on plant growth, plant height, crop yield and soil chemical properties.

Soil amendments may be used to overcome the negative effects of drought stress. So, Riad et al. (2018) observed that amending sandy soil in lysimeter by $0.7 \% \mathrm{PL}$ and $1.0 \% \mathrm{BC}$ alleviated the deleterious effects of water deficit $(75 \%$ depletion) on plants compared with the full irrigation due to improving soil water holding capacity. Also, using PL improves land and water productivity, evaporation and infiltration rates (Ekebafe et al., 2011), while it with BC enhances its positive effects on plant growth (Ruqin et al., 2015) whereas, the germination rate was 76.9$83.7 \%$ with $\mathrm{BC}$ alone, increased to $83.6-85.8 \%$ with $\mathrm{BC}+\mathrm{PL}$, through inhibiting the rise of $\mathrm{pH}$ and $\mathrm{EC}$ due to $\mathrm{BC}$ application. Alkhasha et al. (2018) reported that $0.2-0.8 \%$ PL and $2-8 \%$ BC improved hydro-physical properties of sandy soil, whereas mixture of $0.8 \%$ PL with $8.0 \%$ BC resulted in the highest increase in soil moisture content at field capacity.

Concerning alleviating the drought stresses, Oo et al. (2015) observed that compost and VC were more effective in alleviating salinity and improving growth, plant height and maize dry matter through reducing soil $\mathrm{pH}$ and ECe and increasing its organic carbon. Also, Torkashvand et al. (2017) showed that the substrate containing $20 \% \mathrm{VC}+15 \%$ rice wastes $+15 \%$ manure $+50 \%$ soil had the best yield and can modify the effect of 10-day irrigation interval compared to the 5-day.Therefore, evaluating the impacts of $\mathrm{BC}$, $\mathrm{PL}$ and $\mathrm{VC}$ as well as their mixtures on wheat and maize productivity in sandy soil was the objective of this study.

\section{Materials and Methods}

Lysimeter experiments were conducted at Sakha Agric. Res. Station, Kafr El-Sheikh Gov. $\left(30^{\circ} 3^{\prime} \mathrm{N}\right.$ latitude, $31^{0} 3^{\prime} \mathrm{E}$ longitude) during two successive growing seasons (2018/019 and 2019). The objective of this study was to evaluate the productivity of sandy soil supplied by vermicompost (VC), biochar (BC) and polymer (PL) under two irrigation levels (irrigation after depletion of $50 \%$ and $75 \%$ from available water) as well as their interactions. The irrigation water quantities were calculated for each plot with both soil moisture depletions to compensate soil moisture to field capacity according to Israelsen and Hansen (1962) as follow: 


$$
\mathrm{Q}=(\mathrm{FC}-\mathrm{SMC}) / 100 * \mathrm{Bd} * \mathrm{D} * \mathrm{~A}
$$

Where, Q: quantity of water/plot/irrigation $\left(\mathrm{m}^{3}\right)$, FC: field capacity (\%), SMC: soil moisture content before irrigation, $\mathrm{Bd}$ : bulk density $\left(\mathrm{Mgm}^{-3}\right)$, D: soil depth required to be irrigated (m) and A: plot area $\left(\mathrm{m}^{2}\right)$.

The lysimeter plots $\left(0.455 \mathrm{~m}^{2}\right.$ area and 0.6 $\mathrm{m}$ depth with $0.1 \mathrm{~m}$ gravel filter) were planted by wheat (Gemmeza 11) on Nov., 20 $0^{\text {th }}, 2018$ and harvested on May, $4^{\text {th }}$, 2019, while maize (Hybrid cross 10) was planted on June, 6 $6^{\text {th }}, 2019$ and harvested on Oct., 20 ${ }^{\text {th }}, 2019$. Chemical NPK fertilizers were applied to the soil based on the rate recommended by Ministry of Agriculture recommendation. The experiment was conducted in complete randomize design with three replicates. $0.4 \% \mathrm{PL}, 4.0 \% \mathrm{VC}$ and $1.0 \% \mathrm{BC}$ as
W:W of soil (about $0.395,3.95$ and $0.95 \mathrm{~kg} / \mathrm{plot}$, respectively) as well as their interactions were mixed with the soil in top $15-\mathrm{cm}$ layer before wheat sowing.

The VC was made from rice straw and animal wastes with earthworm species Eisenia fetida and Dendrobaena veneta (Joshi et al. 2014). BC is a fine-grained and porous substance produced through the slow pyrolysis of orange trees at medium temperatures $\left(\right.$ i.e. $\left.650^{\circ} \mathrm{C}\right)$ in absence or limited oxygen source (Odesola and Owoseni, 2010). Both materials in addition to the PL were obtained from the Central Lab. of the Agric. Climate, Agric. Res. Centre, Giza, Egypt and some chemical characteristics of these materials are listed in Table 1. The climate of this region is semi-arid and the temperature, relative humidity, wind speed and the annual precipitation in winter were shown in Table 2.

TABLE 1. Some basic characteristics of the applied soil conditioners

\begin{tabular}{|c|c|c|c|c|c|c|c|}
\hline \multirow{2}{*}{ Materials } & \multirow{2}{*}{$\begin{array}{c}\mathrm{pH} \\
(1: 2.5)\end{array}$} & \multirow{2}{*}{$\begin{array}{c}E C_{e} \\
(d \mathbf{d} / \mathbf{m})\end{array}$} & \multicolumn{3}{|c|}{ Total nutrients $(\%)$} & \multirow{2}{*}{$\begin{array}{c}\mathrm{C} \\
(\%)\end{array}$} & \multirow{2}{*}{$\begin{array}{l}\text { Water holding } \\
\text { capacity }(\%)\end{array}$} \\
\hline & & & $\mathbf{N}$ & $\mathbf{P}$ & $\mathbf{K}$ & & \\
\hline Vermicompost & 7.6 & 4.65 & 1.6 & 1.2 & 1.05 & 18.3 & 150 \\
\hline Biochar & 7.9 & 2.05 & 1.9 & 2.2 & 2.9 & 66.7 & 139 \\
\hline \multicolumn{6}{|c|}{ Super absorbent polymers (SAPS) } & \multicolumn{2}{|c|}{ Major components } \\
\hline \multirow{3}{*}{ A } & \multicolumn{5}{|c|}{ Aqua keep } & \multicolumn{2}{|c|}{ Polyacrylic acid } \\
\hline & \multicolumn{5}{|c|}{ Arasoubu S-107 } & \multicolumn{2}{|c|}{ Polyacrylic acid } \\
\hline & \multicolumn{5}{|c|}{ Aron T-121 } & \multicolumn{2}{|c|}{ Polyacrylic acid } \\
\hline B & \multicolumn{5}{|c|}{ Bargas 700} & \multicolumn{2}{|c|}{ Polyacrylic acid } \\
\hline 1 & \multicolumn{5}{|c|}{ Sanwet H-5000D } & \multicolumn{2}{|c|}{ Polyacrylic acid } \\
\hline & \multicolumn{5}{|c|}{ Composites } & & \\
\hline $\mathrm{B} 1$ & \multicolumn{5}{|c|}{ SAP-20\% } & \multicolumn{2}{|c|}{ Bentonite+SAP-20 $\%$} \\
\hline $\mathrm{K} 1$ & \multicolumn{5}{|c|}{ A SAP- $20 \%$} & \\
\hline & \multicolumn{5}{|c|}{$\mathrm{pH}$} & \multicolumn{2}{|c|}{$\frac{\text { Kaolinite+SAP-20\% }}{7.12}$} \\
\hline 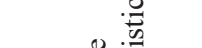 & \multicolumn{5}{|c|}{ Bulk density, $\mathrm{g} \mathrm{cm}^{-3}$} & \multicolumn{2}{|r|}{0.67} \\
\hline$\stackrel{\overrightarrow{0}}{\tilde{Q}}$ & \multicolumn{5}{|c|}{ Real density, $\mathrm{g} \mathrm{cm}^{-3}$} & \multicolumn{2}{|r|}{1.72} \\
\hline ஜீ & \multicolumn{5}{|c|}{ Total porosity, $\%$} & \multicolumn{2}{|r|}{61} \\
\hline ปั & \multicolumn{5}{|c|}{ Water Holding Capacity (WHC), $\mathrm{cm}^{3} \mathrm{~g}^{-1}$} & \multicolumn{2}{|r|}{60} \\
\hline
\end{tabular}

TABLE 2. Meteorological data of the two growing seasons, 2018/019 and 2019

\begin{tabular}{|c|c|c|c|c|c|c|c|}
\hline \multirow{2}{*}{ Year } & \multirow{2}{*}{ Month } & \multicolumn{2}{|c|}{$\mathrm{T}\left({ }^{\circ} \mathrm{C}\right)$} & \multicolumn{2}{|c|}{ RH (\%) } & \multirow{2}{*}{$\begin{array}{l}\text { Wind velocity } \\
(\mathrm{m} / \mathrm{se})\end{array}$} & \multirow{2}{*}{$\begin{array}{l}\text { Precipitation } \\
(\mathbf{m m})\end{array}$} \\
\hline & & Max & Min & Max & Min & & \\
\hline \multirow{6}{*}{2018} & Nov. & 25 & 17.4 & 86.8 & 54.6 & 24.4 & \\
\hline & Dec. & 19.5 & 13.9 & 88.7 & 62.4 & 24.5 & \\
\hline & Jan. & 18.9 & 12.3 & 82.3 & 53.3 & 33.1 & \\
\hline & Feb. & 19.7 & 14.3 & 86.9 & 58.2 & 28.6 & 70.1 \\
\hline & Mar. & 21.1 & 17.6 & 87.8 & 56.6 & 45.7 & \\
\hline & Apr. & 25.1 & 21.3 & 80.8 & 48.9 & 44.8 & \\
\hline \multirow{6}{*}{2019} & May. & 31.9 & 25.4 & 76.4 & 37.9 & 68.4 & \\
\hline & Jun. & 33 & 28 & 81.5 & 50 & 103 & \\
\hline & Jul. & 33.3 & 28.4 & 85.2 & 54.4 & 83.8 & \\
\hline & Aug. & 34.2 & 28.9 & 89.7 & 55.6 & 68.7 & \\
\hline & Sep. & 32.4 & 27.9 & 83.4 & 52.9 & 76.9 & \\
\hline & Oct. & 30.3 & 26.7 & 87.3 & 54.3 & 56.6 & \\
\hline
\end{tabular}


Representative soil samples were taken from surface layer in each plot before planting and after harvesting of each crop and subjected to chemical and physical analysis. Electrical conductivity, EC $\left(\mathrm{dSm}^{-1}\right)$, soluble ions were determined in soil paste extract according to Page et al. (1982). Particle size distribution of soil was measured using pipette method according to Gee and Bauder (1986). Soil bulk density (BD) was determined before experiment and at the end of the experiment for each treatment using core method according to Klute (1986). Total soil porosity (TP) was estimated from the bulk density and particle density of the soil (Black, 1965) using the equation :

$$
\text { Total Porosity }=1-(\rho b / \rho s) \times 100
$$

Where: $\rho$ b: soil bulk density and $\rho$ : soil particle density $\left(2.65 \mathrm{~g} \mathrm{~cm}^{-3}\right)$.

Field capacity and permanent wilting point were calculated from soil moisture tension curve (Black, 1965). Some physical and chemical properties of the soil are shown in Table 3.

Plant height, 100-grain weight, grain yield and straw yield of both crops were measured and subjected to the statistical analyses according to Gomez and Gomez (1984). Treatment means were compared using the least significant difference test (LSD) at 0.05 level.

\section{Results and Discussion}

Effects of soil amendments and soil moisture depletion on soil characters

Soil salinity (ECe)

Because the initial soil salinity was relatively low, its ECe values were slightly increased due to irrigation at $75 \%$ depletion $\left(I_{2}\right)$ after harvesting of wheat and maize (6.5 and $8.8 \%$, respectively) compared to higher irrigation level $\left(\mathrm{I}_{1}\right)$ as shown in Table 4 and Fig. 1. This may be due to the decrease in water applied, leading to slight accumulation of salts. On the other hand, soil amendments differ in their effects on soil salinity. The application of PL combined with BC leads to the highest decreases in ECe with both crops ( -23.4 and $-5.0 \%$, respectively), while PL with VC resulted in the highest accumulations of salts with both crops (6.0 and $17.0 \%$, respectively). Also, the application of soil amendments alleviated the negative effects of irrigation deficit on salt accumulation, whereas ECe values in untreated plots $(\mathrm{CK})$ with wheat or maize under $\mathrm{I}_{2}$ were increased by 9.9 or $13.8 \%$, respectively, while with soil amendments the corresponding increases with both crops were 6.3 or $8.0 \%$, respectively. These results are in somewhat similar to Oo et al.
(2015) who observed that ECe was decreased by application of compost and VC. However, Liang et al. (2006); Rondon et al. (2007) and Zhu et al. (2014) observed increases in ECe with BC due to its large surface area and charge density.

\section{Soil organic matter (OM)}

Soil OM contents after harvesting of both crops slightly affected by irrigation level and clearly affected by soil amendments as shown in Table 4 and Fig. 1. Irrigation at $75 \%$ depletion $\left(\mathrm{I}_{2}\right)$ decreased soil OM contents after harvesting of wheat and maize by 4.0 and $4.2 \%$, respectively comparing to higher irrigation level $\left(\mathrm{I}_{1}\right)$. This decrease may be related to that with $\mathrm{I}_{2}$ treatment inhibits the growth of plant roots and microorganism in soil, leading to decrease in its $\mathrm{OM}$ content. However, the application of soil amendments led to appreciable increase in soil OM. The highest increases in OM with wheat and maize (56.8 and 53.5\%, respectively) were achieved with application of $\mathrm{VC}+\mathrm{BC}+\mathrm{PL}$ followed by $\mathrm{VC}+\mathrm{BC}$ ( 39.2 and $39.4 \%$, respectively), while the lowest increases with both crops (23.0 and $21.1 \%$, respectively) were recorded with PL compared to untreated soil. Moreover, positive effect on soil OM was observed with the interaction between irrigation levels and soil amendments. Therefore, the highest OM contents with both crops were achieved with $\mathrm{PL}+\mathrm{VC}+\mathrm{BC}$ under $\mathrm{I}_{1}$. This trend is in somewhat similar to that observed by Oo et al. (2015).

Bulk density (BD) and total porosity (TP)

Soil BD and TP at the end of the experiment were slightly affected by irrigation level and clearly affected by soil amendments as shown in Table 5 and Fig. 2. The bulk density and total porosity values in soil received lower irrigation water $\left(\mathrm{I}_{2}\right)$ were slightly changed at the end of the experiment compared to that with $\mathrm{I}_{1}$ (1.9 and $-2.5 \%$, respectively). However, the data show that amending soil with $\mathrm{VC}, \mathrm{BC}$ and $\mathrm{PL}$ have the potential to affect its bulk density and total porosity, may be in the same rate but in an opposite trend. The highest decrease in bulk density $(-7.1 \%)$ and the highest increase in total porosity $(8.4 \%)$ were achieved in the soil supplied by $\mathrm{VC}+\mathrm{BC}+\mathrm{PL}$ followed by $\mathrm{VC}+\mathrm{BC}$. These results are agreed with those obtained by Kheir et al. (2017) and Mahmud et al. (2018). In addition, the interaction between irrigation level and soil amendments slightly affected soil OM content. Therefore, the highest $\mathrm{OM}$ contents with wheat and maize ( 0.56 and $0.60 \%$, respectively) were achieved in soil amended by $\mathrm{VC}+\mathrm{BC}+\mathrm{PL}$ with $\mathrm{I}_{1}$, while the lowest contents were recorded in unamended plots with both irrigation levels (0.36$0.38 \%)$. 
TABLE 3. Some physical and chemical properties of soil before experiment

\begin{tabular}{|c|c|c|c|}
\hline Particle size distribution (\%) & Value & Soluble cations $\left(\mathrm{mmol} \mathrm{L}^{-1}\right)$ & Value \\
\hline Sand & 91.4 & $\mathrm{Na}^{+}$ & 15.8 \\
\hline Silt & 4.2 & $\mathrm{~K}^{+}$ & 0.5 \\
\hline Clay & 4.4 & $\mathrm{Ca}^{2+}$ & 6.0 \\
\hline O.M $\left(\mathrm{g} 100 \mathrm{~g}^{-1}\right)$ & 4.1 & $\mathrm{Mg}^{2+}$ & 3.5 \\
\hline Bulk density $\left(\mathrm{g} \mathrm{cm}^{-3}\right)$ & 1.55 & Soluble anions $\left(\mathrm{mmol} \mathrm{L}^{-1}\right)$ & - \\
\hline Total porosity (\%) & 43.4 & $\mathrm{CO}_{3}^{-2}$ & 0.0 \\
\hline FC (\%) & 19.9 & $\mathrm{HCO}_{3}^{-}$ & 3.5 \\
\hline WP (\%) & 9.1 & $\mathrm{Cl}^{-}$ & 11.1 \\
\hline Available water (\%) & 10.8 & $\mathrm{SO}_{4}^{-2}$ & 11.2 \\
\hline $\operatorname{ECe}\left(d S m^{-1}\right)$ & 2.55 & SAR & 7.25 \\
\hline
\end{tabular}

TABLE 4. Mean effects of soil amendments and irrigation levels on soil salinity, and OM

\begin{tabular}{|c|c|c|c|c|c|c|c|c|}
\hline \multirow[b]{2}{*}{ Amendment* } & \multicolumn{3}{|c|}{ Wheat } & \multicolumn{5}{|c|}{ Maize } \\
\hline & $\begin{array}{c}\text { ECe } \\
\left(\mathrm{dS} \mathrm{m}^{-1}\right)\end{array}$ & $\pm \%$ & $\begin{array}{l}\text { OM } \\
(\%) \\
\end{array}$ & $\pm \%$ & $\begin{array}{c}\text { ECe } \\
(\mathrm{dS} / \mathrm{m})\end{array}$ & $\pm \%$ & $\begin{array}{l}\text { OM } \\
(\%)\end{array}$ & $\pm \%$ \\
\hline $\mathrm{CK}$ & 2.66 & 0.0 & 0.37 & 0.0 & 2.71 & 0.0 & 0.36 & 0.0 \\
\hline $\mathrm{VC}$ & 2.57 & -3.2 & 0.50 & 33.8 & 2.74 & 1.1 & 0.47 & 31.0 \\
\hline PL & 2.57 & -3.4 & 0.46 & 23.0 & 2.65 & -2.0 & 0.43 & 21.1 \\
\hline $\mathrm{BC}$ & 2.43 & -8.7 & 0.49 & 31.1 & 2.58 & -4.8 & 0.47 & 32.4 \\
\hline $\mathrm{VC}+\mathrm{PL}$ & 2.82 & 6.0 & 0.51 & 37.8 & 3.17 & 17.0 & 0.49 & 36.6 \\
\hline $\mathrm{VC}+\mathrm{BC}$ & 2.09 & -21.5 & 0.52 & 39.2 & 2.66 & -1.7 & 0.50 & 39.4 \\
\hline $\mathrm{BC}+\mathrm{PL}$ & 2.04 & -23.4 & 0.48 & 28.4 & 2.57 & -5.0 & 0.49 & 38.0 \\
\hline $\mathrm{VC}+\mathrm{BC}+\mathrm{PL}$ & 2.63 & -0.9 & 0.58 & 56.8 & 2.58 & -4.8 & 0.55 & 53.5 \\
\hline Mean $\mathrm{I}_{1}$ & 2.39 & 0.0 & 0.50 & 0.0 & 2.59 & 0.0 & 0.48 & 0.0 \\
\hline Mean $\mathrm{I}_{2}$ & 2.55 & 6.5 & 0.48 & -4.0 & 2.82 & 8.8 & 0.46 & -4.2 \\
\hline $\mathrm{I}_{1}$ with $\mathrm{A}$ & 2.37 & 0.0 & 0.51 & 0.0 & 2.6 & 0.0 & 0.50 & 0.0 \\
\hline $\mathrm{I}_{2}$ with A & 2.52 & 6.3 & 0.49 & -5.8 & 2.81 & 8.0 & 0.47 & -6.0 \\
\hline $\mathrm{I}_{1}$ without $\mathrm{A}$ & 2.53 & 0.0 & 0.36 & 0.0 & 2.53 & 0.0 & 0.34 & 0.0 \\
\hline $\mathrm{I}_{2}$ without A & 2.78 & 9.9 & 0.38 & 5.6 & 2.88 & 13.8 & 0.37 & 8.8 \\
\hline
\end{tabular}

TABLE 5. Mean effects of soil amendments and irrigation levels on soil bulk density (BD) and total porosity (TP)

\begin{tabular}{ccccccccc}
\hline Amendment* & $\begin{array}{c}\text { BD } \\
\left(\mathbf{g} / \mathbf{c m}^{\mathbf{3}}\right)\end{array}$ & $\mathbf{\pm \%}$ & $\mathbf{T P} \%$ & $\mathbf{\pm \%}$ & $\mathbf{F C} \%$ & $\mathbf{\pm \%}$ & $\mathbf{A W} \%$ & $\pm \mathbf{\%}$ \\
\hline CK & 1.54 & 0.0 & 42.4 & 0.0 & 20.1 & 0.0 & 10.0 & 0.0 \\
VC & 1.52 & -1.4 & 42.7 & 0.6 & 21.5 & 7.0 & 10.7 & 6.9 \\
PL & 1.58 & 2.2 & 40.5 & -4.4 & 20.3 & 1.1 & 10.1 & 1.0 \\
BC & 1.49 & -3.0 & 43.6 & 2.8 & 20.4 & 1.7 & 10.2 & 1.6 \\
VC+PL & 1.51 & -2.1 & 43.1 & 1.6 & 22.5 & 12.0 & 11.2 & 11.9 \\
VC+BC & 1.49 & -3.5 & 43.9 & 3.4 & 22.5 & 12.1 & 11.2 & 12.1 \\
BC+PL & 1.54 & 0.2 & 41.7 & -1.5 & 20.9 & 4.1 & 10.4 & 4.0 \\
VC+BC+PL & 1.43 & -7.1 & 46.0 & 8.4 & 22.8 & 13.6 & 11.4 & 13.5 \\
Mean I & 1.50 & 0.0 & 43.5 & 0.0 & 21.4 & 0.0 & 10.7 & 0.0 \\
Mean I & 1.53 & 1.9 & 42.4 & -2.5 & 21.3 & -0.8 & 10.6 & -0.8 \\
\hline
\end{tabular}

*CK: Control, VC: vermicompost, BC: biochar, PL: polymer, $\mathrm{I}_{1}: 50 \%$ depletion, $\mathrm{I}_{2}: 75 \%$ depletion 

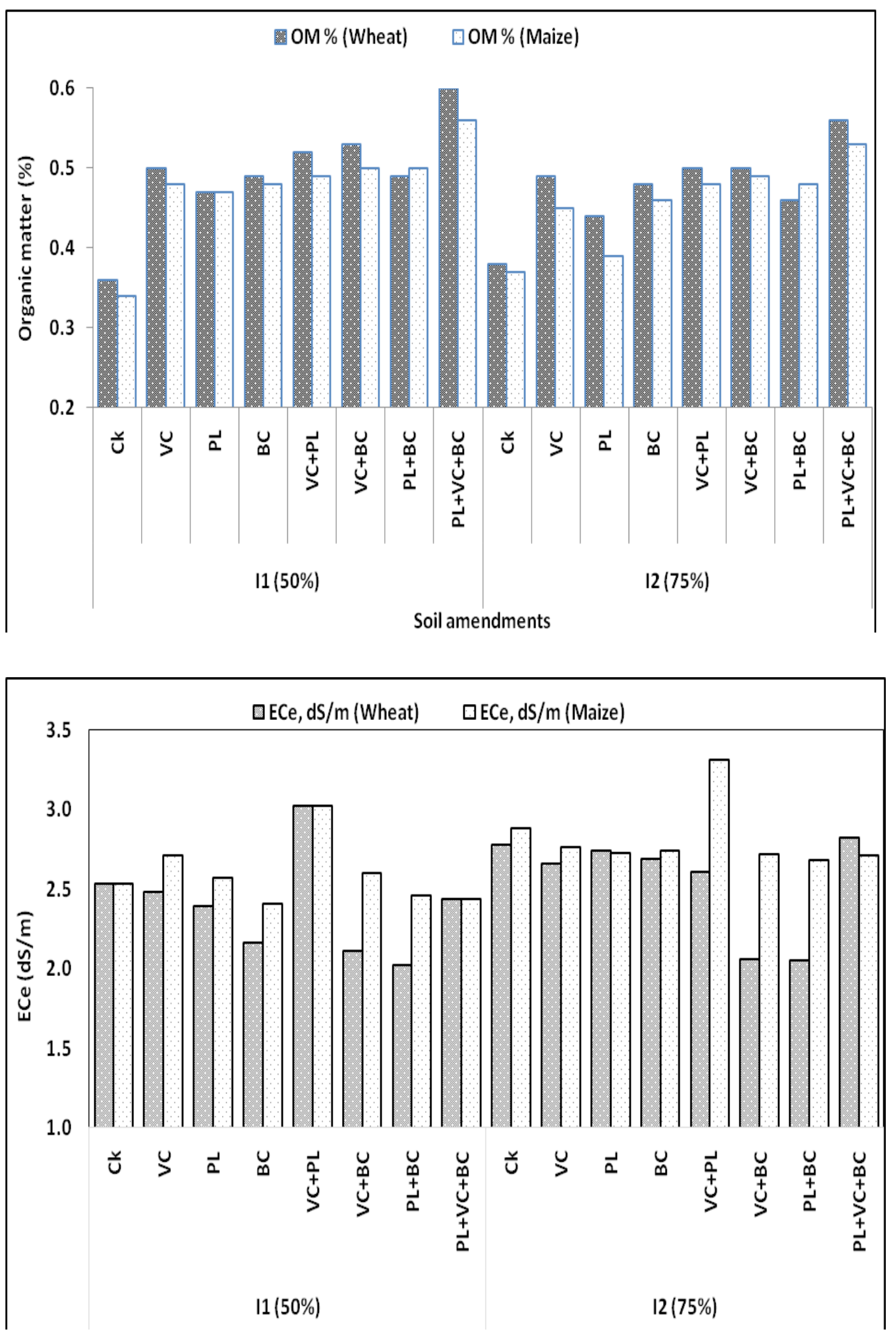

Fig. 1. Effects of soil amendments and irrigation levels on ECe and OM,

${ }^{*} \mathrm{CK}$ : Control, VC: vermicompost, BC: biochar, PL: polymer, $\mathrm{I}_{1}: 50 \%$ depletion, $\mathrm{I}_{2}: 75 \%$ depletion. 

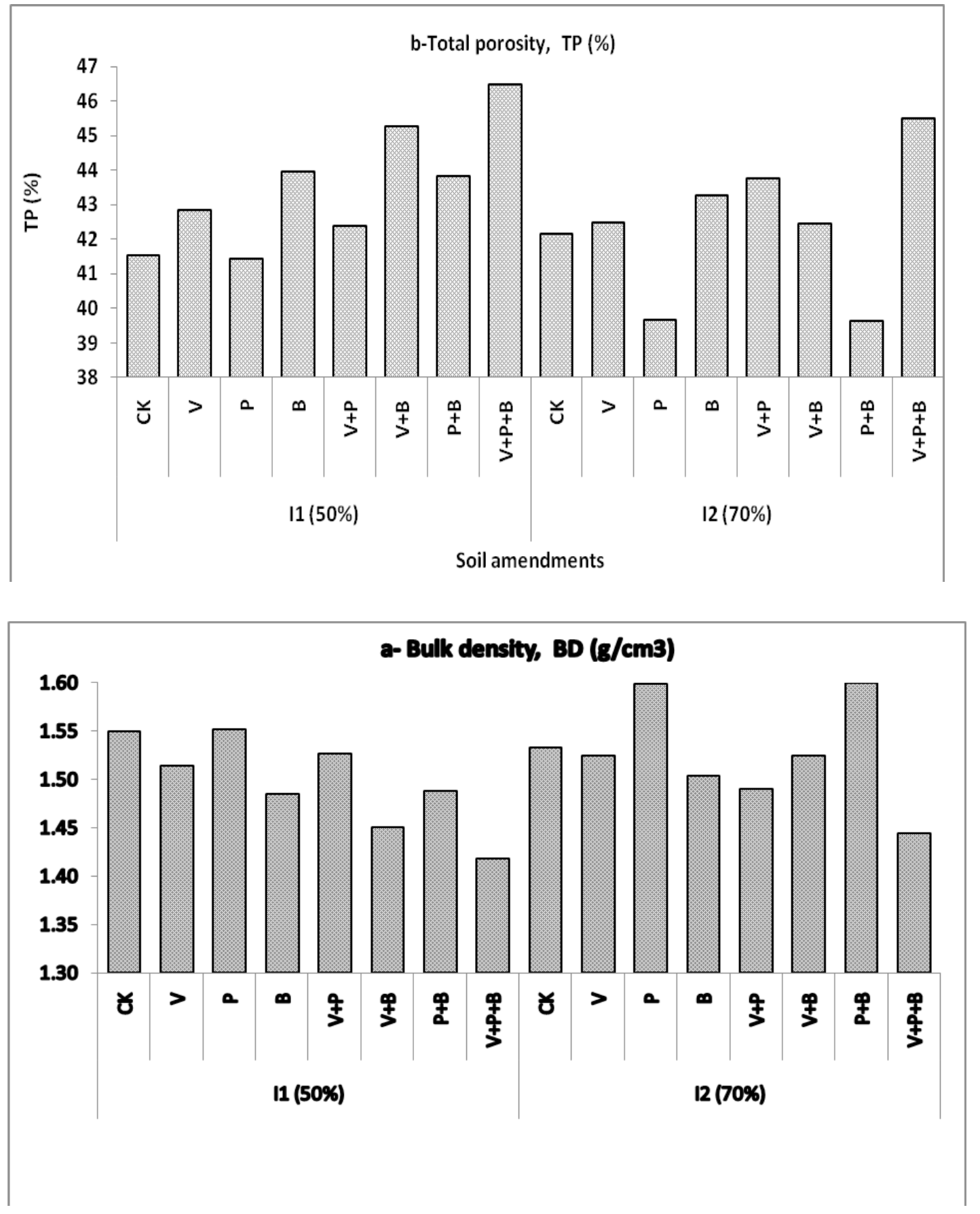

Fig. 2. Effects of soil amendments and irrigation levels on a-BD and b- TP,

*CK: Control, VC: vermicompost, BC:biochar, PL: polymer, $\mathrm{I}_{1}: 50 \%$ depletion, $\mathrm{I}_{2}: 75 \%$ depletion

Field capacity $(F C)$ and available water $(A V)$

As shown in Table 5 and Fig. 3, the irrigation levels not affect both of soil field capacity and available water. However, soil amendments appreciably affected its hydro-physical properties. The plots supplied by $\mathrm{PL}+\mathrm{VC}+\mathrm{BC}$ achieved the highest increases in soil field capacity and available water (13.6 and $13.5 \%$, respectively) followed by VC with BC or with PL (about $12 \%$ for both parameters). The lowest effects on both parameters were recorded with application of $\mathrm{PL}$ (1.1 and $1.1 \%$, respectively) or BC (1.7 and 1.6\%, respectively) when compared to the control. These results are agreed with that obtained by Ibrahim et al. (2015), Kheir et al. (2017), Alkhasha et al. (2018) and Riad et al. (2018) who observed that soil amendments improved hydro-physical properties of sandy soils in lysimeter experiment such as water holding capacity. 

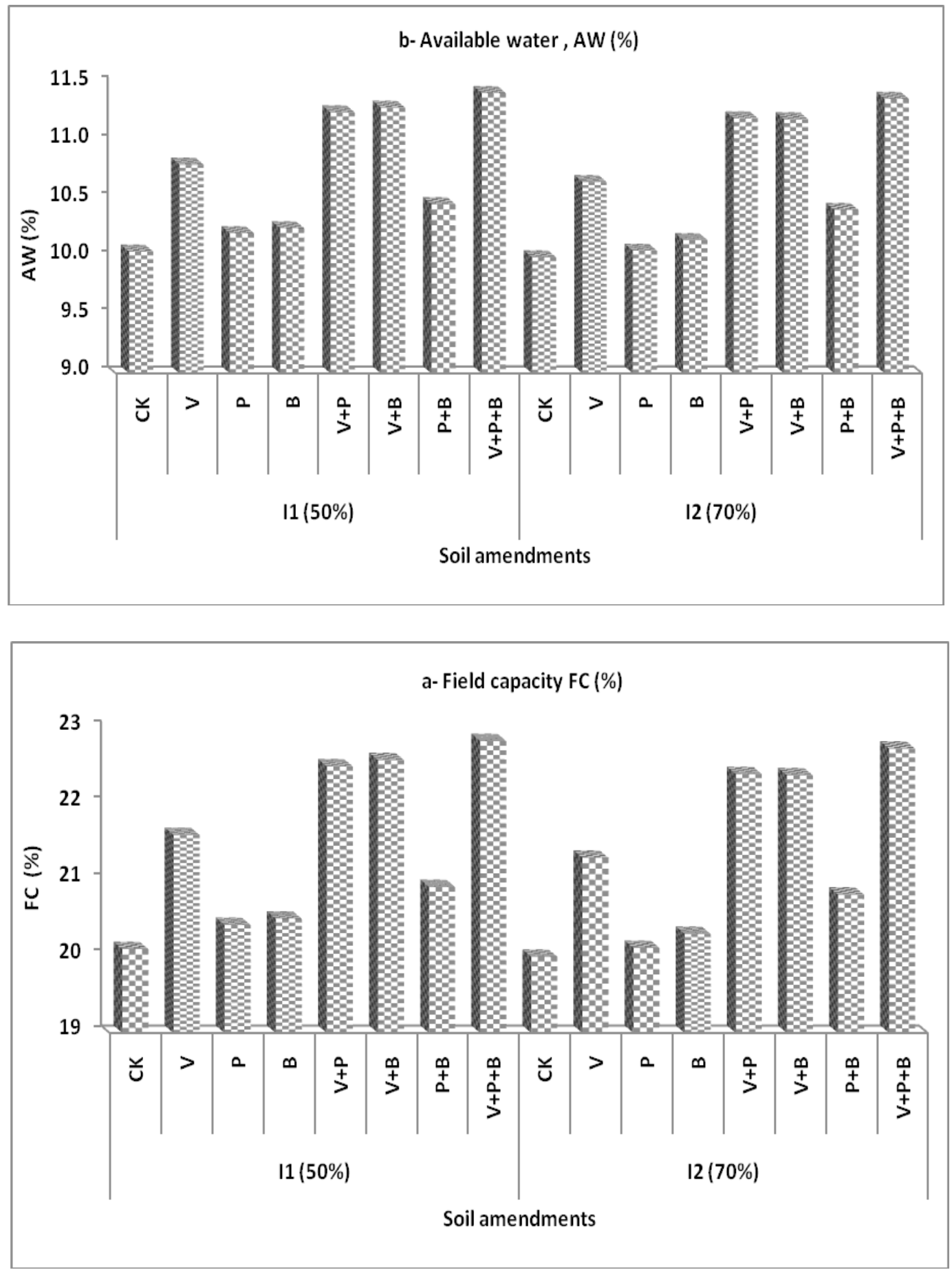

Fig. 3. Effect of soil amendments and irrigation levels on a. field capacity and $\mathbf{b}$. available water, ${ }^{*} \mathrm{CK}$ : Control, PL:polymer, VC: vermicompost, BC: biochar, $\mathrm{I}_{1}: 50 \%$ depletion, $\mathrm{I}_{2}: 75 \%$ depletion

Effect of soil amendments and soil moisture depletion on plant parameters

Plant height and 100-grain weight

The data illustrated in Table 6 and Fig. 4, showed significant effects of irrigation levels and soil amendments on growth parameters of wheat and maize. Pronounced decreases in plant height and 100-grain weight of both crops were found with increasing the irrigation depletion from $50 \%$ $\left(\mathrm{I}_{1}\right)$ to $75 \%\left(\mathrm{I}_{2}\right)$. The 100-grain weight in wheat and maize was decreased with $\mathrm{I}_{2}$ by 12.9 and $2.9 \%$, respectively, while plant height of both crops was decreased by 19.7 and $17.2 \%$, respectively compared to that with $\mathrm{I}_{1}$. The reductions in both 
parameters with water deficit $\left(\mathrm{I}_{2}\right)$ may be due to the hindering impact of drought stress on cell division and enlargement (Taiz et al. 2015), lower rates of water and nutrients absorption (Farooq et al. 2009) and the partial or full closure of stomata to prevent water loss through the transpiration process (Osakabe et al. 2014). These results are in agreement with those obtained by Osman (2015), Riad et al. (2018), Emam et al. (2007) and Akbar et al. (2010) who reported that plant growth parameters and 1000-grain weight were greatly reduced with drought stress.

The applications of soil amendments as well as their combinations significantly increased 100-grain weight and plant height of both crops compared to that recorded from the untreated plots (CK). The application of soil amendments individually affected the plant height and 100-grain weight according the following descending order: $\mathrm{VC}>\mathrm{PL}>\mathrm{BC}$. The addition of $\mathrm{VC}$ with $\mathrm{PL}$ and $\mathrm{BC}$ was the most effective treatment on both parameters under the both irrigation levels, followed by $\mathrm{VC}$ combined with $\mathrm{Pl}$ or $\mathrm{BC}$, while the untreated plots in most cases recorded the lowest values. Eventually, the highest increases in 100-grain weight in wheat and maize (16.3 and 62.25 , respectively) and the highest increases in their heights (22.4 and $27.2 \%$, respectively) were achieved with VC combined with PL and $\mathrm{BC}$ compared to that recorded in the untreated plots. The positive effects of soil amendments such as VC may due to the presence of available nutrients, large amounts of microbial life and diversity and plant growth regulating hormones (Allardice, 2015), so it a potential source of nutrients for sustainable crop production (Suthar, 2009). Also, VC with BC provides some benefits such as pathogen suppression and increasing of crop productivity (Shoaf, 2014).

Additionally, the significant impacts due to the interaction of irrigation levels with soil amendments were observed as shown in Fig.4. The highest values of 100-grian weight in wheat and maize (6.0 and $45.5 \mathrm{~g}$, respectively) and plant height in both crops $(91.8 \mathrm{~cm}$ and $183.3 \mathrm{~cm}$, respectively) were achieved with $\mathrm{PL}+\mathrm{VC}+\mathrm{BC}$ treatment under $\mathrm{I}_{1}$, while the lowest values of both parameters were recorded in untreated plots under $\mathrm{I}_{2}$. These results may attribute to that the soil amendments such as BC has a pronounced enhancement in vegetative growth parameters of crops under reduced irrigation (Akhtar et al., 2014, Batool et al., 2015, Liu et al., 2017 and Nadeem et al., 2017). Also, BC improves soil physicochemical properties under normal and abiotic-stress conditions (Abel et al., 2013 and Hammer et al., 2015), or it enhances soil fertility, water use efficiency and carbon sequestration (Akhtar et al., 2014 and Batool et al., 2015). Similarly, PL under reduced irrigation level stimulates the growth of different crops (Kamal and El-Shazly, 2013; Shahrokhian et al. 2013; Fernando et al. 2014; El Sagan, 2015; Beig et al. 2014; El-Tohamy et al. 2014 and Ahmed et al., 2015b).

TABLE 6. Mean effects of soil amendments and irrigation levels on plant height $(\mathrm{cm})$ and 100-grain weight $(\mathrm{g})$ of wheat and maize.

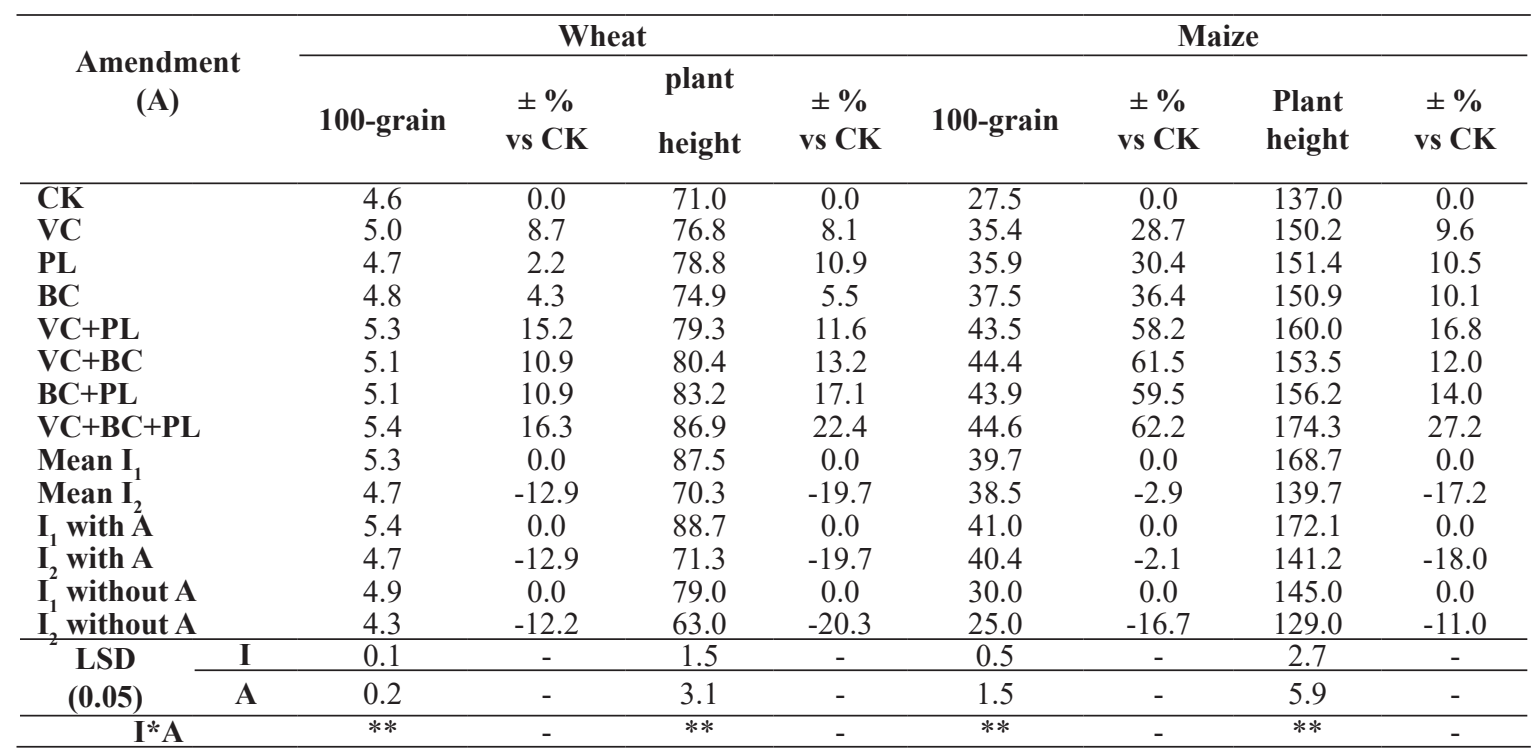

*CK: Control, VC: vermicompost, BC: biochar, PL: polymer, $\mathrm{I}_{1}: 50 \%$ depletion, $\mathrm{I}_{2}: 75 \%$ depletion 
Moreover, soil amendments under this study slightly mitigated the adverse effect of drought stress on wheat heights and grain filling in maize. Therefore, irrigation deficit $\left(\mathrm{I}_{2}\right)$ without soil amendments decreased wheat heights by $20.3 \%$, while with soil amendments the decrease was $19.7 \%$. Also, the decrease in 100-grain weight in maize due to $I_{2}$ without amendments was $16.7 \%$, while with soil amendments the decrease was only $2.1 \%$, compared to $\mathrm{I}_{1}$. These results may be attributed to that the soil amendments reduced the stresses of water deficiency on crops (Ahmad et al., 2013) through improving soil chemical, physical and biological properties (HuesoGonzález et al. 2014 and Mann et al. 2011). Also, the positive effects may due to increasing soil water-holding capacity with soil amendments (Akhter et al. 2004, and Ahmed et al. 2015a) and slow release of water through soil (Orzeszyna et al., 2006 and Khadem et al., 2010), causing better water use efficiency and plant growth under normal or drought stress conditions (Kim et al., 2010, Kamal and El-Shazly, 2013, Shahrokhian et al., 2013 and El Sagan, 2015).
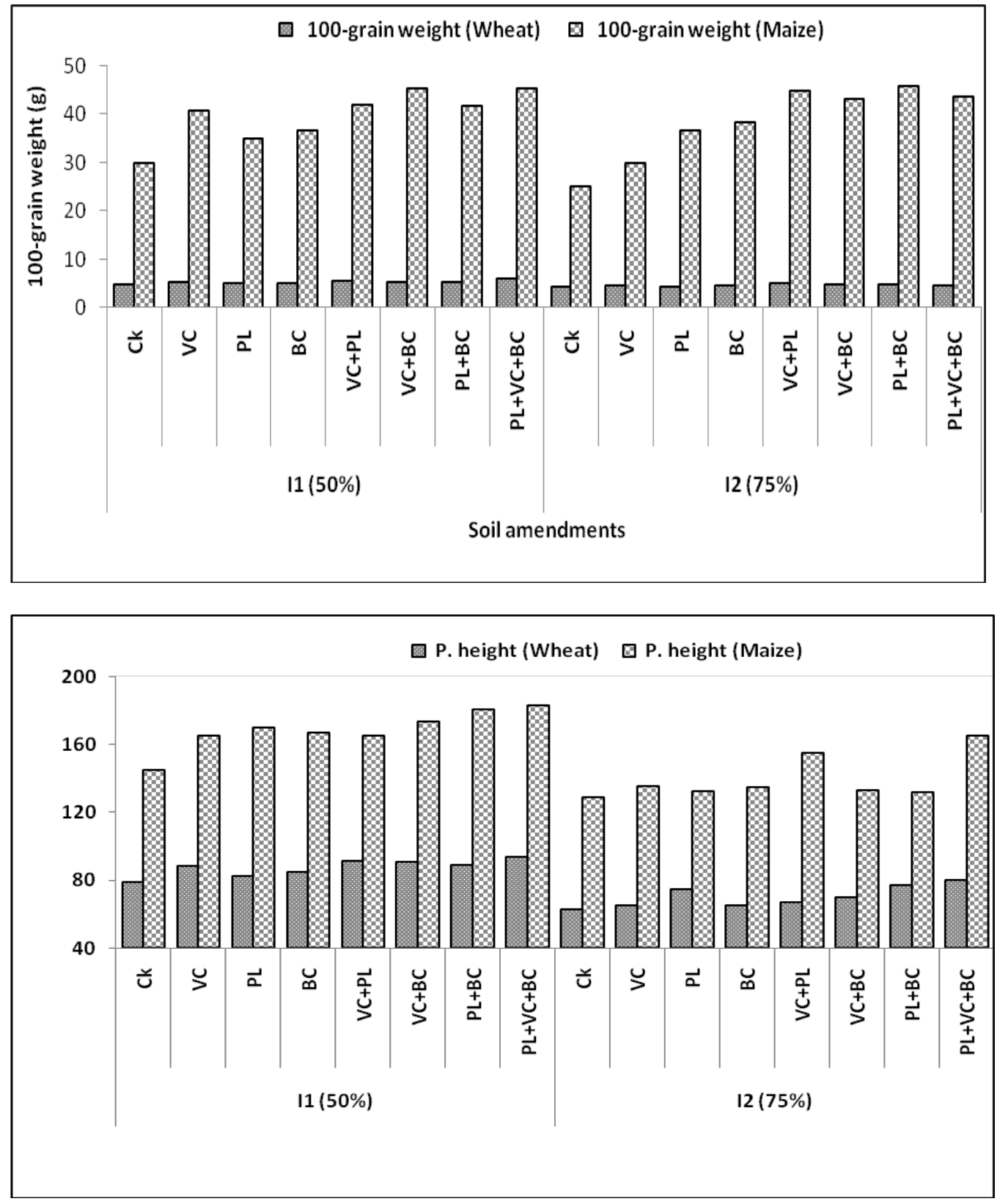

Fig. 4. Effects of soil amendments and irrigation levels on 100-grain weight and plant height, *CK: Control, VC: vermicompost, BC: biochar, PL: polymer, $\mathrm{I}_{1}: 50 \%$ depletion, $\mathrm{I}_{2}: 75 \%$ depletion 
Grain and straw yields

It could be concluded through the statistical analysis that wheat and maize yields were significantly affected by soil amendments and irrigation levels as illustrated in Table 7 and Fig. 5. Concerning the effect of irrigation level, the increase of irrigation depletion from 50 to $75 \%$ decreased the grain and straw yield by 21.9 and $18.7 \%$, respectively in wheat and 17.2 and $17.1 \%$, respectively in maize. The inhibition of crop yield with the drought stress $\left(\mathrm{I}_{2}\right)$ may be attributed to stomatal closure resulting in reductions of transpiration rate and $\mathrm{CO}_{2}$ uptake during photosynthesis (Neumann, 2008) or due to a decrease in intercepted light which ultimately reduced its efficiency into the economic parts (Wajid et al., 2007). Similar reductions in crop yield under drought condition were observed by Moghaddam et al. (2012) and Ibrahim et al. (2005).

In case of soil amendments, data show that the application of VC, PL and BC as well as their interactions led to pronounce increases in grain and straw yields of wheat and maize compared to the untreated plots $(\mathrm{Ck})$. The decreases in yield of both crops approximately showed a trend as $\mathrm{PL}+\mathrm{VC}+\mathrm{BC}>\mathrm{VC}+\mathrm{BC}>\mathrm{PL}+\mathrm{BC}>\mathrm{VC}+\mathrm{PL}>\mathrm{VC}$ $>\mathrm{BC}>\mathrm{PL}>\mathrm{CK}$. Therefore, the highest increases in grain yield of wheat and maize (34.4 and 60.1\%, respectively) were achieved with combination of $\mathrm{VC}+\mathrm{PL}+\mathrm{BC}$, while the highest straw yields in both crops (17.8 and 49.1\%, respectively) were achieved with VC combined with BC. The lowest increases in grain in both crops (3.4 and $16.1 \%$, respectively) and straw (8.9 and $12.1 \%$, respectively) were recorded in plots treated by PL when compared with the untreated plots. The increase in crop yield with soil amendments such as VC may be related to their effectiveness in improving its growth through alleviating the drought and salinity stress (Ooet al. 2015). Also, $\mathrm{VC}$ and $\mathrm{BC}$ increase crop productivity may due to suppress pathogens (Shoaf, 2014), or enhance the nutrient uptake by plants (Ruqin et al., 2015).

TABLE 7. Mean effect of soil amendments and irrigation levels on yield $\left(\mathrm{g} / \mathrm{m}^{2}\right)$

\begin{tabular}{|c|c|c|c|c|c|c|c|c|c|}
\hline \multirow{2}{*}{\multicolumn{2}{|c|}{ Amendment* }} & \multicolumn{4}{|c|}{ Wheat } & \multicolumn{4}{|c|}{ Maize } \\
\hline & & Grain & $\begin{array}{c} \pm \% \\
\text { vs.CK }\end{array}$ & Straw & $\begin{array}{c} \pm \% \\
\text { vs.CK }\end{array}$ & Grain & $\begin{array}{c} \pm \% \\
\text { vs CK }\end{array}$ & Straw & $\begin{array}{l} \pm \% \\
\text { vs.CK }\end{array}$ \\
\hline CK & & 458 & 0.0 & 382 & 0.0 & 770 & 0.0 & 570 & 0.0 \\
\hline $\mathrm{VC}$ & & 504 & 10.0 & 450 & 17.7 & 942 & 22.3 & 642 & 12.6 \\
\hline PL & & 474 & 3.4 & 416 & 8.9 & 894 & 16.1 & 639 & 12.1 \\
\hline BC & & 487 & 6.2 & 424 & 10.9 & 1020 & 32.5 & 653 & 14.6 \\
\hline $\mathrm{VC}+\mathrm{PL}$ & & 518 & 13.1 & 439 & 14.8 & 1080 & 40.3 & 670 & 17.5 \\
\hline $\mathrm{VC}+\mathrm{BC}$ & & 510 & 11.2 & 450 & 17.8 & 1107 & 43.8 & 850 & 49.1 \\
\hline $\mathrm{BC}+\mathrm{PL}$ & & 507 & 10.7 & 446 & 16.8 & 1103 & 43.2 & 803 & 40.9 \\
\hline $\mathrm{VC}+\mathrm{BC}$ & & 616 & 34.4 & 450 & 17.8 & 1233 & 60.1 & 827 & 45.1 \\
\hline Mean I & & 572 & 0.0 & 477 & 0.0 & 1115 & 0.0 & 773 & 0.0 \\
\hline Mean I & & 447 & -21.9 & 387 & -18.7 & 923 & -17.2 & 641 & -17.1 \\
\hline $\mathbf{I}_{1}$ with & & 579 & 0.0 & 485 & 0.0 & 1152 & 0.0 & 793 & 0.0 \\
\hline $\mathbf{I}_{2}$ with & & 454 & -21.6 & 393 & -18.8 & 956 & -17.0 & 582 & -26.7 \\
\hline$I_{1}$ witho & & 520 & 0.0 & 420 & 0.0 & 850 & 0.0 & 630 & 0.0 \\
\hline$I_{2}$ witho & & 443 & -23.8 & 394 & -18.1 & 750 & -18.8 & 634 & -19.0 \\
\hline \multirow{3}{*}{$\begin{array}{c}\text { LSD } \\
(0.05)\end{array}$} & I & 10.7 & - & 6.5 & - & 16.4 & - & 11.7 & - \\
\hline & $\mathbf{A}$ & 19.6 & - & 16.3 & - & 39.7 & - & 27.6 & - \\
\hline & $\mathbf{I} * \mathbf{A}$ & $* *$ & - & $* *$ & - & $* *$ & - & $* *$ & - \\
\hline
\end{tabular}

*CK: Control, VC: vermicompost, BC: biochar, PL: polymer, $\mathrm{I}_{1}: 50 \%$ depletion, $\mathrm{I}_{2}: 75 \%$ depletion. 
Ultimately, the interaction between soil moisture depletion and soil amendments significantly impacts the yield of both crops as shown in Fig. 5. Therefore, the highest grain and straw yields in wheat $(708$ and $512 \mathrm{~g} /$ $\mathrm{m}^{2}$, respectively) and maize (1300 and $914 \mathrm{~g} /$ $\mathrm{m}^{2}$, respectively) were obtained from the plots amended by $\mathrm{VC}+\mathrm{PL}+\mathrm{BC}$ with $50 \%$ depletion $\left(\mathrm{I}_{1}\right)$. The lowest values of both parameters in wheat (396 and $344 \mathrm{~g} / \mathrm{m}^{2}$, respectively) and maize (690 and $510 \mathrm{~g} / \mathrm{m}^{2}$, respectively) were recorded in untreated plots under $75 \%$ depletion $\left(\mathrm{I}_{2}\right)$.

Moreover, application of soil amendments may in somewhat alleviate the negative effects of drought stress on grain yield of both crops. So, the grain yield of wheat with $75 \%$ depletion was decreased by $21.6 \%$ with soil amendments, but without amendments the decrease was $23.8 \%$. Also, the grain yield of maize subjected to $75 \%$ depletion was decreased by $17.0 \%$ with soil amendments, while without amendments it was depressed by $18.8 \%$, compared to $50 \%$ depletion (Table 7). This behavior may be attributed to that applying soil amendments such as PL and BC under drought condition alleviate its deleterious effects in sandy soils due to enhancing water holding capacity, improves soil characteristics and crop yield (Ekebafe et al., 2011 and Riad et al., 2018).
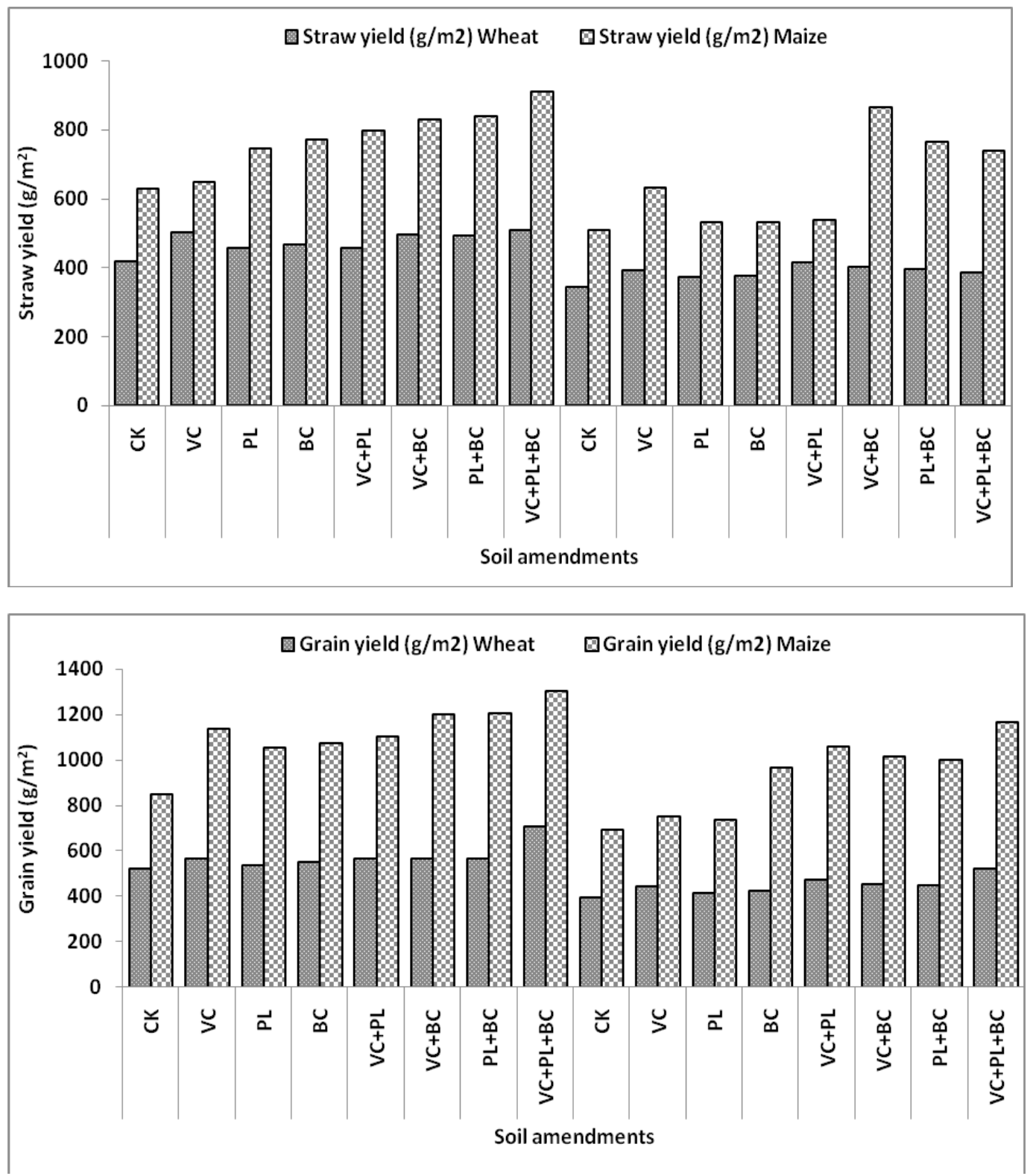

Fig. 5. Effect of soil amendments and irrigation levels on grain and straw yields,

*CK: Control, VC: vermicompost, BC: biochar, PL: polymer, $\mathrm{I}_{1}: 50 \%$ depletion, $\mathrm{I}_{2}: 75 \%$ depletion 
Water applied (Wa) and water productivity (WP)

The data illustrated in Table 8 and Fig. 6, show the effects of irrigation levels and soil amendments on Wa and WP values. The data show an obvious reduction in water applied to wheat and maize (16.8 and $20.0 \%$, respectively) with $75 \%$ depletion $\left(\mathrm{I}_{2}\right)$ compared to $50 \%$ depletion $\left(\mathrm{I}_{1}\right)$. Also, under $\mathrm{I}_{2}$, the value of WP was slightly decreased with wheat $(5.9 \%)$, but slightly increased with maize (3.4\%) when compared with $\mathrm{I}_{1}$. The variations in WP values depend on the amounts of water applied and the grain yield of both crops under both irrigation levels. Similar reduction in WP was observed by Zhang et al. (2008) and Ghodsi et al. (2008) who observed that higher water use efficiency for wheat was achieved with water stress.

TABLE 8. Mean effects of soil amendments and irrigation levels on water applied, Wa $\left(\mathrm{L} / \mathrm{m}^{2}\right)$ and water productivity, WP $\left(\mathrm{kg} / \mathrm{m}^{3}\right)$.

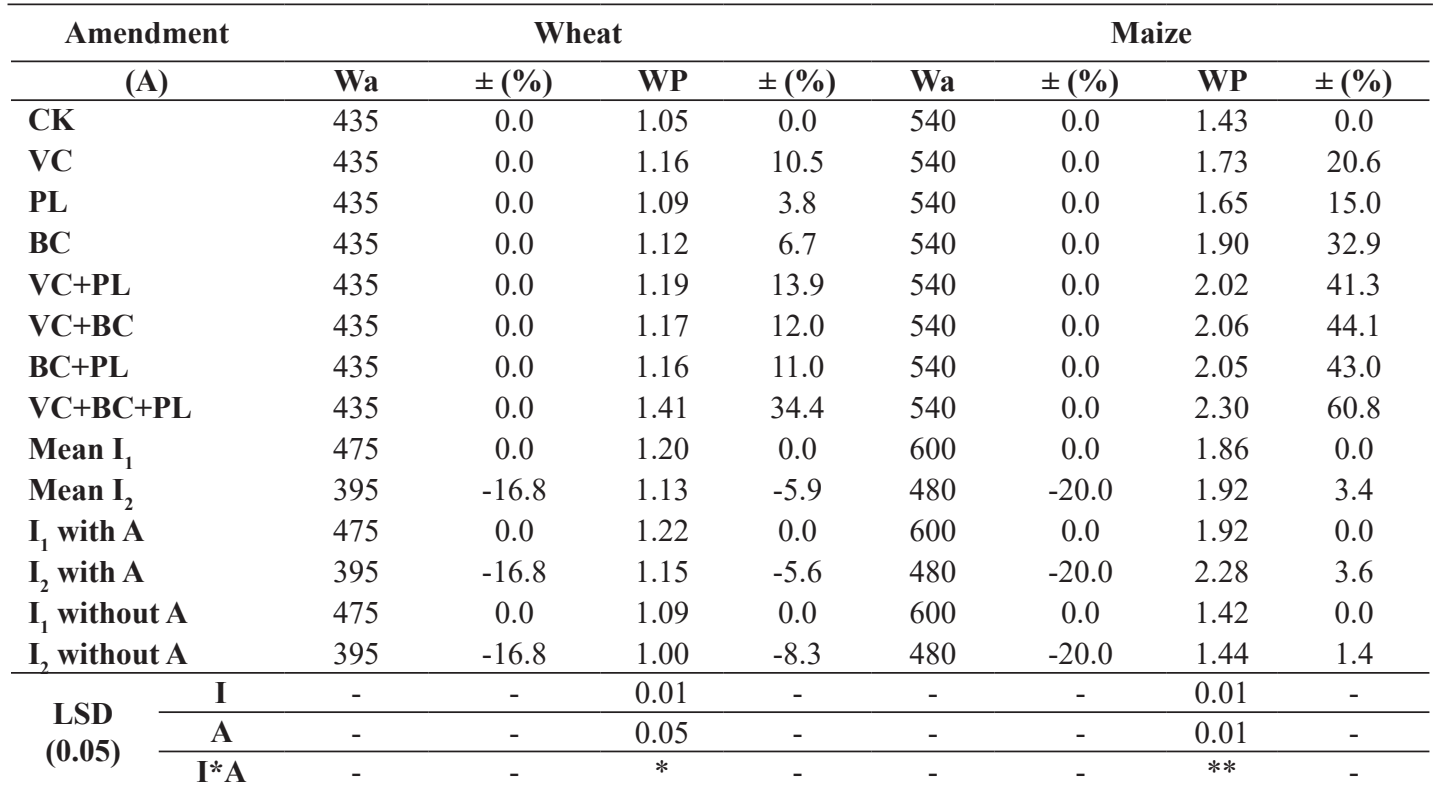

*CK: Control, VC: vermicompost, BC: biochar, PL: polymer, $\mathrm{I}_{1}: 50 \%$ depletion, $\mathrm{I}_{2}: 75 \%$ depletion.

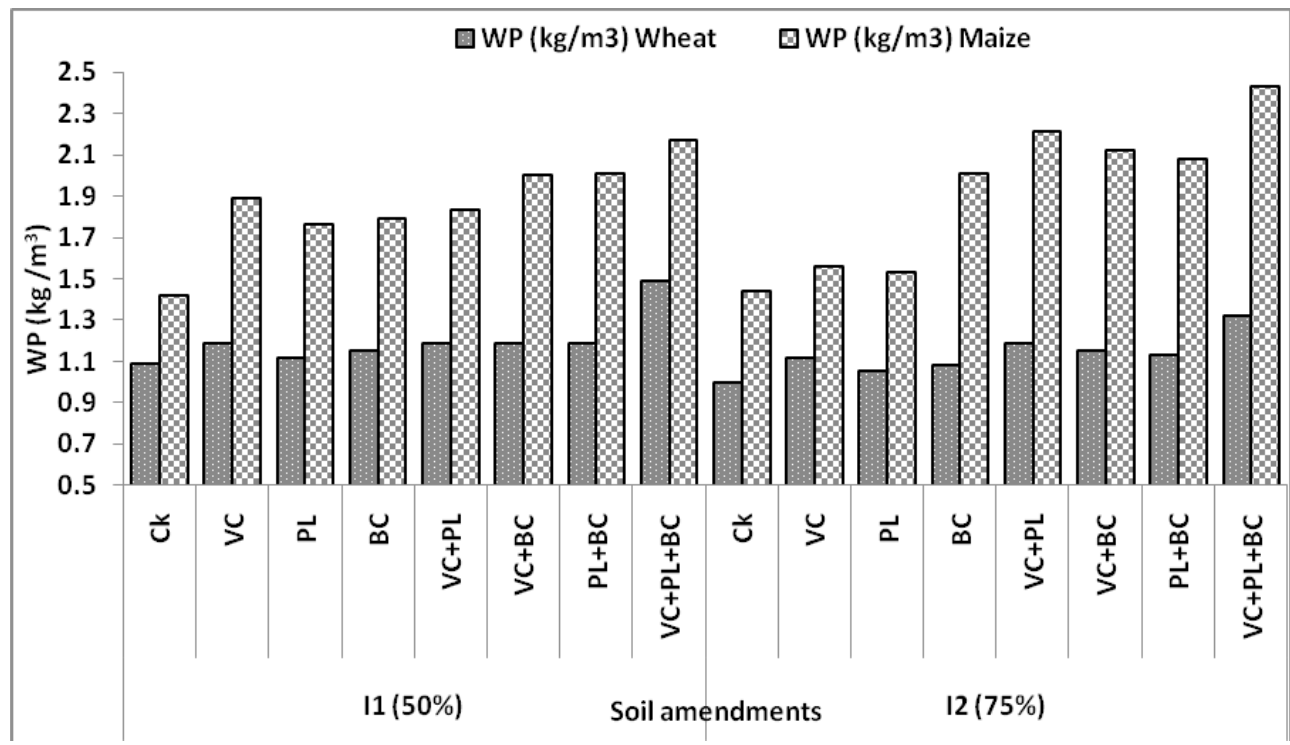

Fig. 6. Effects of soil amendments and irrigation levels on water productivity of wheat and maize, *CK: Control, VC: vermicompost, BC: biochar, PL: polymer, $\mathrm{I}_{1}: 50 \%$ depletion, $\mathrm{I}_{2}: 75 \%$ depletion 
The role of soil amendments in improving WP may due to their positive effects on crop yield. The VC was the most effective amendment on WP followed by BC and PL. The highest increases in WP values for wheat and maize (34.4 and 60.8\%, respectively) were achieved with the combination of $\mathrm{VC}+\mathrm{PL}+\mathrm{BC}$, while the lowest increases $(3.8$ and $15.0 \%$, respectively) were recorded from PL treated plots comparing to untreated plots. Moreover, the interaction between irrigation levels and soil amendments was effective on WP values in both crops (Fig. 6). The highest WP values were obtained in plots amended by $\mathrm{VC}+\mathrm{PL}+\mathrm{BC}$ with $\mathrm{I}_{1}$ for wheat $\left(1.49 \mathrm{~kg} / \mathrm{m}^{3}\right)$ or with $\mathrm{I}_{2}$ for maize $\left(2.43 \mathrm{~kg} / \mathrm{m}^{3}\right)$, while the lowest values (1.00 and $1.44 \mathrm{~kg} / \mathrm{m}^{3}$, respectively) were recorded in untreated plots with $\mathrm{I}_{2}$. Similar trend was observed by Ekebafe et al. (2011).

\section{Conclusion}

This study evaluated the productivity of sandy soil supplied by vermicompost, biochar and polymer under two irrigation levels (50 and 75\% depletions). It could be concluded that application of $4.0 \%$ vermicompost with $1 \%$ biochar and $0.4 \%$ polymer significantly enhanced growth, yield and water productivity and improved soil porosity and field capacity under both irrigation levels. In conclusion, applying vermicompost combined with biochar and polymer is a proper approach to help crop cultivation in sandy soil, whereas they maintain long-term productivity of these soils and mitigate the deleterious effects of drought stresses.

\section{References}

Abel, S., Peters, A., Trinks, S., Schonsky, H., Facklam, M. and G. Wessolek (2013) Impact of biochar and hydrochar addition on water retention and water repellency of sandy soil. Geoderma, 202-203, 183191. doi:10.1016/j. geoderma.2013.03.003

Ahmad, S., Ghafoor, A.,Akhtar, M.E., and M.Z. Khan (2013) Ionic displacement and reclamation of saline-sodic soils using chemical amendments and crop rotation. Land Degrad. Dev., 24: 170-178.

Ahmed, E.M., Aggor, F.S., Nada, S.S. and S.I. Hawash (2015a) Synthesis and characterization of super absorbent polymers for agricultural purposes. Int. J. Sci. Eng. Res., 6 (3), 282-287.

Ahmed, E.M., El-Tohamy, W.A., El-Abagy, H.M.H., Aggor, F.S. and S.S. Nada (2015b) Response of snap bean plants to super absorbent hydrogel treatments under drought stress conditions. Current Science International, 4 (3), 467-472.

Env. Biodiv. Soil Security Vol. 4 (2020)
Aiad, M.A.E.F. (2019) Productivity of Heavy Clay Soils as Affected by Some Soil Amendments Combined with Irrigation Regime. Environment, Biodiversity and Soil Security, 3, 147-162.

Akbar, A., Maoyedi Boyce, A.N. and S.S. Barakbah (2010) The performance of durum and bread wheat genotype associated with yield and yield component under different deficit conditions. Aus. J. Bas and App. Sci., 41: 106-113.

Akhtar, S.S., Li, G., Andersen, M.N. andF. Liu (2014) Biochar enhances yield and quality of tomato under reduced irrigation. Agricultural Water Management, 138, 37-44. doi:10.1016/j. agwat.2014.02.016

Akhter, J., Mahmood, K., Malik, K.A., Mardan, A., Ahmad, M. and M.M. Iqbal (2004) Effects of hydrogel amendment on water storage of sandy loam and loam soils and seedling growth of barley, wheat and chickpea. Plant Soil Environ. 50 (10), 463-469.

Alkhasha, A., Al-Omran, A. and A. Aly (2018) Effects of Biochar and Synthetic Polymer on the HydroPhysical Properties of Sandy Soils. Sustainability, 10, 4642; doi:10.3390/su10124642.www.mdpi. com/journal/sustainability

Allardice, R. (2015) Does the application of vermicompost solid and liquid extracts influence the growth, N-nutrition and soil microbial diversity of the legume, Lupinus angustifolius?. Master of Science, Faculty of Science, Stellenbosch University. https://scholar.sun.ac.za.

Amer, M. and F.A. El-Emary (2018) Impact of Foliar with Nano-silica in Mitigation of Salt Stress on Some Soil Properties, Crop-Water Productivity and Anatomical Structure of Maize and Faba Bean. Environment, Biodiversity and Soil Security, 2, 2538.

Azeem, M., Hayat, R., Hussain, Q., Ahmed, M., Imran, M.and D. E. Crowley(2016) Effect of biochar amendment on soil microbial biomass, abundance and enzyme activity in the mash bean field. $J$ of Biodiversity and Environmental Sciences (JBES), 8 (6): 1-13.

Batool, A., Taj, S., Rashid, A., Khalid, A., Qadeer, S., Saleem, A.R. andM.A. Ghufran (2015) Potential of soil amendments (biochar and gypsum) in increasing water use efficiency of Abelmoschus esculentus L. Moench. Front. Plant Sci., 6 (Article733), 1-13. doi:10.3389/ fpls.2015.00733

Bayoumy, M. A., Khalifa, T.H.H. and H.M. Aboelsoud 
(2019) Impact of some Organic and Inorganic Amendments on Some Soil Properties and Wheat Production under Saline-Sodic Soil, J. Soil Sci. and Agric Eng., Mansoura Univ., 10 (5): 307-313.

Beig, A.V.G., Neamati, S.H., Tehranifar, A. and H. Emami (2014) Evaluation of chlorophyll fluorescence and biochemical traits of lettuce under drought stress and super absorbent or bentonite application. J. Stress Physiology \& Biochemistry, 10 (1), 301-315.

Black, C.A. (1965) Methods of Soil Analysis. Amer. Soc. Agro. Inc., Madison, Wisconsin, U.S.A.

Diatta, A. A. (2016) Effects of Biochar Application on soil Fertility and Pearl Millet (Pennisetum glaucum L.) Yield. Master of Science, Faculty of the Virginia Polytechnic Institute and State University, USA.

Edmunds, C. W. (2012) The Effects of Biochar Amendment to Soil on Bioenergy Crop Yield and Biomass Composition. Masters Theses, Graduate School, University of Tennessee, Knoxville Trace: Tennessee Research and Creative Exchange.

Ekebafe,L. O., Ogbeifun, D. E. and F. E. Okieimen (2011) Polymer Applications in Agriculture. Biokemistri, 23 (2):81-89.

E1 Sagan, M.A.M. (2015) Effect of polymer on drought tolerance of tomato (Solanum lycopersicum L.). European Journal of Academic Essays, 2 (9), 7282.

El-Kallawy, W. and A.G. Hefeina (2019) Comparative study on rice germination and seedling growth under salinity and drought stresses. Environment, Biodiversity and Soil Security, 3, 109-117.

El-Tohamy, W.A., El-Abagy, H.M.H., Ahmed, E.M., Aggor, F.S. and S.I. Hawash (2014) Application of super absorbent hydrogel poly (acrylate/ acrylic acid) for water conservation in sandy soil. Transaction of the Egyptian Society of Chemical Engineering, 40 (2), 1-8.

Emam, Y., Ranjbar, A. M. and M.J. Bahrani (2007) Evaluation of yield and yield components in wheat genotypes under post- anthesis drought stress. $J$. Sci. \& Technol. Agric. \& Natur. Resour., 11: 328339.

Farooq, M., Wahid, A., Kobayashi, N., Fujita, D. and S.M.A. Basra (2009) Plant drought stress: effects, mechanisms and management. Agron. Sustain. Dev., 29 (1), 185-212. doi:10.1051/agro:2008021.

Fernando, T.N., Aruggoda, A.G.B., Disanayaka, C.K. and S. Kulathunge (2014) Evaluating the effects of different watering intervals and prepared soilless media incorporated with a best weight of super absorbent polymer (SAP) on growth of tomato. Journal of Engineering and Technology of the Open Univ. of Sri Lanka (JET-OUSL), 2 (2):1-14.

Gautam, D. K., Bajracharya, R. M., and B. K.Sitaula (2017) Effects of Biochar and Farm Yard Manure on Soil Properties and Crop Growth in an Agroforestry System in the Himalaya. Sustainable Agriculture Research; 6 (4): 74-82.

Gee, G. W. and J. W. Bauder (1986) Particle-size Analysis. P. 383 - 411. In: A.L. Page (Ed.). Methods of Soil Analysis, Part 1, physical and mineralogical methods.

Ghodsi, M., Jalal Kamali, R., Mazaheri, D. and M. R. Chaichi (2008) Water and radiation use efficiency in different developmental stages in four bread wheat cultivars under moisture stress conditions. Desert, 12: 129-137.

Glaser, B., Lehmann, J. and W. Zech, (2002) Ameliorating physical and chemical properties of highly weathered soils in the tropics with charcoalA review. Biol Fertil Soil, 35: 219-230.

Gomez, K. A. and A. A. Gomez (1984) "Statistical Procedures for Agricultural Research". $2^{\text {nd }}$ ed. John Willey and sons Pub. PP. 139-153.

Gupta, R.K. and Monika (2016) Biochar: Effects on Crop Productivity and Soil Properties. International Journal of Tropical Agriculture, 34, 6, 2016.

Hammer, E.C., Forstreuter, M., Rillig, M.C. and J. Kohler (2015) Biochar increases arbuscular mycorrhizal plant growth enhancement and ameliorates salinity stress. Applied Soil Ecology, 96, 114-121. doi:10.1016/j. apsoil.2015.07.014

Hossain, M. K., Strezov, V, Chan, K. Y. and P. F. Nelson (2010) Agronomic properties of wastewater sludge biochar and bioavailability of metals in production of cherry tomato (Lycopersicon esculentum). Chemosphere, 78: 1167-71.

Hueso-González, P., Martínez-Murillo, J.F. and J.D. Ruiz-Sinoga, (2014) The impact of organic amendments on forest soil properties under Mediterranean climatic conditions. Land Degrad. Dev., 25: 604-612.

Ibrahim, M., Rafiq, M., Hussain, A., Basra, S.M.A., Ahmad, A., Shah, A.W., Anwar, J. and MA. Goheer (2005) Effect of irrigation on Agronomic traits of wheat (Triticum aetsivum L.). Int. J. Biol. Biotech., 2: 751-759.

Env. Biodiv. Soil Security Vol. 4 (2020) 
Ibrahim, M.M., Mahmoud, E.K. and A. D. Ibrahim (2015) Effects of vermicompost and water treatment residuals on soil physical properties and wheat yield. Int. Agrophys., 29: 157-164. doi: 10.1515/intag-2015-0029.

Israelsen, O.W. and V.E. Hansen (1962) Irrigation Principles and practices ( $3^{\text {rd }}$ ed.) John Willey and Son Inc., New York.

Jin, F., Ran C., Anwari, Q.A., Geng, Y.Q., Guo, L.Y., Li, J.B., Han, D., Zhang, X.Q., Liu, X.and X.W. Shao (2018) Effects of biochar on sodium ion accumulation, yield and quality of rice in salinesodic soil of the west of Songnen plain, northeast China. Plant Soil Environ., 64 (12): 612-618.

Joshi, R., Singh, J. and A.P.Vig (2014) Vermicompost as an effective organic fertilizer and biocontrol agent: effect on growth, yield and quality of plants. Rev. Environ. Sci. Biotechnol. DOI 10.1007/s11157014-9347-1

Kamal, A.M. and M.M. El-Shazly (2013) Maximizing the productivity and water use efficiency of tomato plants (Lycopersicon esculentum mill.) cultivated in the new reclaimed lands using different irrigation water quantities and some water saving substances. J. Plant Production, Mansoura Univ., 4 (9), 13991416.

Kanwal,S. Ilyas, N., Shabir, S., Saeed, M, Gul, R., Zahoor, M., Batool,N., andR. Mazhar (2018) Application of biochar in mitigation of negative effects of salinity stress in wheat (Triticum aestivum L.). J. Plant Nutrition, 41, 4.

Khadem, S.A., Galavi, M., Ramrodi, M., Mousavi, S.R., Rousta, M.J. and P. Rezvani-moghadam (2010) Effect of animal manure and superabsorbent polymer on corn leaf relative water content, cell membrane stability and leaf chlorophyll content under dry condition. Australian Journal of Crop Science, 4 (8), 642-647.

Kheir, A.M.S., Bayumy, M.A. and H.M. Aboelsoud (2017) Effectiveness of natural soil conditioners and irrigation regime on: 1-Loamy sand soil properties, crop production and water productivity. Menoufia J. Soil Sciences, 2: 227-264.ISSN 23570822.

Kim, S., Iyer, G., Nadarajah, A., Frantz, J.M. and A.L. Spongberg (2010) Polyacrylamide hydrogel properties for horticultural applications. International Journal of Polymer Analysis and Characterization, 15 (5), 307-318. doi:10.1080/10 23666X.2010.493271

Env. Biodiv. Soil Security Vol. 4 (2020)
Klute, A. (1986) Methods of Soil Analysis, Part 1, Physical and Mineralogical properties, Amer., Society, Agronomy, Monograph 9, $2^{\text {nd }}$ ed. Madison, Wisc., USA.

Lehmann, J. and S. Joseph (2009) Biochar for environmental management: an introduction. In: Lehmann, J., Joseph, S. (Ed.), Biochar for Environmental Management: Science and Technology. Earthscan, London.

Liang, B., Lehmann, J., Solomon, D., Kinyangi, J., Grossman, J., O’Neill, B., Skjemstad, J.O., Thies, J., Luizão, F.J., Petersen, J. and E.G. Neves (2006) Black carbon increases cation exchange capacity in soils. Soil Sci Soc Am. J. 70: 1719-1730.

Liu, C., Liu, F., Ravnskov, S., Rubæk, G.H., Sun, Z. and M.N. Andersen (2017) Impact of wood biochar and its interactions with mycorrhizal fungi, phosphorus fertilization and irrigation strategies on potato growth. J. Agro. Crop Sci., 203 (2), 131-145. doi: $10.1111 /$ jac. 12185 .

Mahmud, M., Abdullah, R. and J. S. Yaacob (2018) Effect of Vermicompost Amendment on Nutritional Status of Sandy Loam Soil, Growth Performance, and Yield of Pineapple (Ananas comosus var. MD2) under Field Conditions. Agronomy, 8, 183.www. mdpi.com/journal/agronomy.

Mann, K.K., Schumann, A.W., Obreza, T.A., Sartain, J.B., Harris, W.G. and S. Shukla (2011) Analyzing the efficiency of soil amendments and irrigation for plant production on heterogeneous sandy soils under greenhouse conditions. J. Plant Nutr. Soil Sci., 174: 925-932.

Moghaddam, H.A, Galavi, M., Soluki, M., Siahsar, B.A., Mousavinik, S.M. and M. Heidari (2012) Effects of deficit irrigation on yield, yield components and some morphological traits of wheat cultivars under filed condition, International Journal of Agriculture: Research and Review. 2 (6), 825-83, 2012.

Mosa, A.A., El-Ghamry, A., Al-Zahrani, H., Selim, E.M. and A. El-Khateeb (2017) Chemically modified biochar derived from cotton stalks: characterization and assessing its potential for heavy metals removal from wastewater. Environment, Biodiversity and Soil Security, 1, 33-45.

Mukta, S., Rahman, M. M. and M. G. Mortuza (2015) Yield and Nutrient Content of Tomato as Influenced by the Application of Vermicompost and Chemical Fertilizers. J. Environ. Sci. \& Natural Resources, 8 (2): 115-122, 2015. 
Nadeem, S.M., Imran, M., Nayeed, M., Khan, M.Y., Ahmed. M., Zahir, Z.A. and D.E. Crowley (2017) Synergistic use of biochar, compost and plant growth-promoting rhizobacteria for enhancing cucumber growth under water deficit conditions. $J$. Sci. Food Agric., 97 (15), 5139-5145. doi: 10.1002/ jsfa. 8393 .

Neumann, P.M. (2008) Coping mechanisms for crop plants in drought-prone environments. Ann. Bot., 101: 901-907.

Obia, A., Mulder, J., Martinsen, V., Cornelissen, G. and T. Børresen (2016) In situ effects of biochar on aggregation, water retention and porosity in light-textured tropical soils. Soil Tillage Res., 155: $35-44$.

Odesola, I.F. and T.A. Owoseni (2010) Small scale biochar production technologies: a review. $J$. Emerg. Trends Eng. Appl. Sci.,1 (2), 151-156.

Oo, A. N., Iwai, C. B. and P. Saenjan (2015) Soil Properties and Maize Growth in Saline and Nonsaline Soils Using Cassava-Industrial Waste Compost and Vermicompost With or Without Earthworms. Land Degrad. Develop. 26: 300-310. DOI: $10.1002 / \mathrm{ldr} .2208$.

Orzeszyna, H., Garlikowski, D. and A. Pawlowski (2006) Using of geocomposite with superabsorbent synthetic polymers as water retention element in vegetative layers. Int. Agrophysics, 20: 201-206.

Osakabe, Y., Osakabe, K., Shinozaki, K. and L.S.P. Tran (2014) Response of plants to water stress. Frontiers Plant Sci., 5 (86), 1-8. doi:10.3389/ fpls.2014.00086.

Osman, H.S. (2015) Enhancing antioxidant-yield relationship of pea plant under drought at different growth stages by exogenously applied glycine betaine and proline. Annals of Agricultural Sciences, 60 (2), 389-402. doi:10.1016/j. aoas.2015.10.004

Page, A.L. (1982) Methods of Soil Analysis. Part 1: Physical properties and part 2: Chemical and microbiological properties. ( $3^{\text {rd }}$ ed.) Amer. Soc. Agron., In Soil Sci. Soc. Amer. Inc., Madison, Wisconsin, USA.

Qayyum, M. F., Abid, M., Danish, S., Saeed, M. K. and M. A. Ali (2015) Effects of Various Biochars on Seed Germination and Carbon Mineralization in an Alkaline soil. Pak. J. Agri. Sci., 51 (4), 977-982.

Riad, G.S., Youssef, S.M., Abu El-Azm Nashwa A.I., and M. E. Ahmed (2018) Amending Sandy Soil with Biochar or/and Superabsorbent Polymer
Mitigates the Adverse Effects of Drought Stress on Green Pea. Egypt. J. Hort, 45 (1):169-183.

Rondon, M. A., Lehmann, J., Ramírez, J., and M. Hurtado (2007) Biological nitrogen fixation by common beans (Phaseolus vulgaris L.) increases with biochar additions. Biol Fertil Soils, 43: 699708.

Ruqin, F., Jia, L., Shaohua, Y., Yunlai,Z. and Z. Zhenhua (2015) Effects of Biochar and Super Absorbent Polymer on Substrate Properties and Water Spinach Growth. Pedosphere, 25 (5): 737-748.

Saad, M. and H.A. Abo-Koura (2018) Improvement of Sorghum (Sorghum bicolor 1. Moench) Growth and Yield under Drought Stress by Inoculation with Bacillus cereus and Foliar Application of Potassium Silicate. Environment, Biodiversity and Soil Security, 2, 205-221.

Samson B.K., Hasan, M. and L.J. Wade (2002) Penetration of hardpans by rice lines in the rainfed lowlands. Field Crops Res.,76: 175-188.

Schulz, H. and B. Glaser (2012) Effects of biochar compared to organic and inorganic fertilizers on soil quality and plant growth in a greenhouse experiment. J. Plant Nutr. Soil Sci., 175: 410-422.

Shahrokhian, Z., Mirzaei, F. and A. Heidari (2013) Effects of super absorbent polymer on tomato's yield under water stress conditions and its role in the maintenance and release of nitrate. World Rural Observations, 5 (2), 15-19.

Shoaf, N. L. (2014) Biochar and Vermicompost Amendments in Vegetable Cropping Systems: Impacts on Soil Quality, Soil-Borne Pathogens and Crop Productivity. Master of Science, Purdue Univ., West Lafayette, Indiana, USA.

Suthar, S. (2006) Effect of vermicompost and inorganic fertilizer on wheat (Triticum aestivum) production. Nature, Environ. Pollution Technol., 5, 197-201.

Suthar, S. (2009) Impact of vermicompost and composted farmyard manure on growth and yield of garlic (Allium stivum L.) field crop. International Journal of Plant Production, 3 (1): 1735-6814, 1735-8043

Taiz, L., Zeiger, E., Møller, M. and A. Murphy (2015) Physiology and Development, $6^{\text {th }}$ ed. Sinauer Associates, Sunderland, Miami, USA.

Torkashv and, A. Mohammadi., Shahin, H.R. and M. Mohammadi (2017) Growth of olive saplings in different media containing artificial and natural super absorbents at two irrigation intervals. Global

Env. Biodiv. Soil Security Vol. 4 (2020) 
J. Environ. Sci. Manage., 3 (3): 311-322. DOI: 10.22034/gjesm.2017.03.03.008.

Wajid, A., Hussain, K., Maqsood, M., Ahmad, A. and A. Hussain (2007) Influence of drought on water use efficiency in wheat in semi-arid regions of Punjab. Soil \& Environ., 26: 64-68.

Wang, X., He, M., Li, F., Liu, Y., Zhang, H. and C. Liu (2008) Coupling effects of irrigation and nitrogen fertilization on grain protein and starch quality of strong-gluten winter wheat. Front Agric. China, 2: 274-280.

Yao, Y., Gao, B., Zhang, M., Inyang, M. and A. R. Zimmerman, (2012) Effect of biochar amendment on sorption and leaching of nitrate, ammonium, and phosphate in a sandy soil. Chemosphere, 89: 14671471.
Zhang, X., Han, H., Ning, L.T., Shan, Y. and M. Bai (2008) Radiation use efficiency and yield of winter wheat under deficit irrigation in North China. J. P. Soil Environ. 54: 313-319.

Zheng, W., Sharma, B.K. and N. Rajagopalan (2010) Using Biochar as a Soil Amendment for Sustainable Agriculture. Illinois Sustainable Technology Center, University of Illinois at Urbana-Champaign, Agriculture Grant Program, Illinois Department of Agriculture, ISTC/UIUC, 1 E. Hazelwood Drive; Champaign, IL 61820, 217-333-7276 (office), wzheng@istc.illinois.edu

Zhu, Q. H., Peng, X. H., Huang, T. Q., Xie, Z. B. and N. M. Holden (2014) Effect of biochar addition on maize growth and nitrogen use efficiency in acidic red soils. Pedosphere, 24: 699-708. 